\title{
Factors Associated with Handwash Behavior in Elementary School Students Medan Sunggal
}

\author{
Nadya Ulfa Tanjung ${ }^{1}$, Ayu Soraya ${ }^{2}$, Sri Wahyuni ${ }^{3}$ \\ ${ }^{1}$ FKM Universitas Islam Negeri Sumatera Utara, ${ }^{2,3}$ Institut Kesehatan Sumatera Utara \\ Email corespondensi : ${ }^{1}$ nadyaulfa.tanjung@gmail.com
}

\begin{tabular}{|c|c|}
\hline $\begin{array}{c}\text { Track Record } \\
\text { Article } \\
\text { Diterima : } 12 \text { December } 2021 \\
\text { Dipublikasi: } 20 \text { January } 2022\end{array}$ & $\begin{array}{l}\text { School-age children are an asset in the future that need to be maintained in improving and } \\
\text { protecting health. School-age children, an age group that is vulnerable to health problems } \\
\text { because they are in a school environment, are a source of transmission of diseases related to } \\
\text { PHBS, especially Hand Washing with Soap (CTPS) is one of the indicators of PHBS in } \\
\text { educational institutions. The general objective of the study was to determine the factors related to } \\
\text { the behavior of washing hands with soap in State Elementary School Students } 060916 \text { Medan } \\
\text { Sunggal. This type of research is quantitative with a cross sectional approach. The total } \\
\text { population in the study conducted was } 301 \text { students, with a sample of } 70 \text { respondents. The } \\
\text { research sample was taken using a non-random sampling technique, namely purposive sampling. } \\
\text { The results of univariate and bivariate analysis used statistical tests and chi square tests } \\
\text { (significant level 0.05). The results showed as many as } 35.7 \% \text { of respondents had good hand } \\
\text { washing behavior with soap. Furthermore, from the results of the study, it was found that there } \\
\text { was no relationship between knowledge (P-value }=0.083 \text { ) and the behavior of washing hands } \\
\text { with soap and there was a relationship between habits (P-value }=0.000 \text { ) and the behavior of } \\
\text { washing hands with soap. Meanwhile, the variables of facilities and infrastructure and teacher } \\
\text { support are no longer analyzed for bivariate analysis, because the respondents' answers are } \\
\text { homogeneous. From the results of this study, the conclusions obtained are that there is no } \\
\text { relationship between knowledge and hand soap, there is a relationship between habits and } \\
\text { behavior of washing hands with soap, facilities and infrastructure, teacher support, the answers of } \\
\text { the respondents are homogeneous. Suggestions from this study are that students can increase } \\
\text { awareness and behavior of washing hands with soap properly. } \\
\text { Keywords: Behavior, CTPS, Students, Elementary School }\end{array}$ \\
\hline
\end{tabular}

\section{Introduction}

Clean and Healthy Living Behavior (PHBS) is a collection of behaviors that are practiced on the basis of awareness as a result of learning that makes a person or family able to help themselves in the health sector and play an active role in realizing public health. Clean and Healthy Behavior is divided into various arrangements, namely Household Orders, Educational Institutions (Schools), Health Institutions, Workplaces and Public Places (Kemenkes, 2014). Clean and Healthy Living Behavior (PHBS) in the school environment has eight indicators, namely washing hands using running water and using soap, consuming healthy snacks, using clean and healthy latrine facilities, exercising regularly, eradicating mosquito larvae in schools, not smoking in the school environment., measuring weight and height, and throwing garbage in the place provided. These eight indicators must be done properly in order to create healthy behavior in the school environment. 
One of the indicators of Clean and Healthy Living Behavior (PHBS) is washing hands with running water and soap, which is a set of behaviors that are carried out because of awareness of learning outcomes, which enable individuals or families to maintain and maintain health and play an active role in creating a healthy society. One of the main pillars of Healthy Indonesia and is one of the strategies to reduce the burden on the state and society towards health financing, namely school PHBS (Kemenkes RI, 2014).

The Clean and Healthy Life Practice (PHBS) for elementary school-aged children starts with brushing teeth properly, washing hands, and cleaning nails and hair. The existence of a Clean and Healthy Lifestyle (PHBS) plays an important role in reducing the risk of getting diseases caused by unclean and healthy behavior. Diseases that will arise due to low hygiene and healthy behavior include intestinal worms, diarrhea, toothache, skin pain, malnutrition and so on which ultimately result in the low health status of Indonesia (Pramono M, 2011).

According to WHO, 100,000 Indonesian children die from diarrheal disease every year, while data from the Ministry of Health shows that out of 1,000 population, there are 300 people who suffer from diarrheal disease throughout the year (Indonesian Health Profile 2011). In addition, there are still as many as 40-60\% of school-age children who suffer from intestinal worms (Lubis, 2013). The 2009 Indonesian Health Profile presents data that, there are as many as $64.41 \%$ of facilities that have been fostered by the environment to implement a clean and healthy life. The facilities consist of educational institutions as much as $67.52 \%$, workplaces as much as $59.15 \%$, and other environments as much as 62.26\% (Depkes RI, 2010).

The United Nations Children's Fund (UNICEF) found that hand washing with soap (CTPS) can also reduce $50 \%$ of the incidence of avian influenza (Ministry of Health, 2010). The Department of Infection and Tropical Diseases in London, England stated that washing hands with soap can reduce mortality from diarrheal diseases and acute respiratory infections by $42-47 \%$. The study also estimates that hand washing can prevent 1 million child deaths across Indonesia (BIMKES, 2013).

Based on data from Riskesdas (Basic Health Research) in 2013, Clean and Healthy Living Behavior (PHBS) in the Indonesian population, brushing teeth every day has been carried out as much as $93.8 \%$ but the correct brushing behavior is still low at $2.3 \%$, while PHBS in $95.7 \%$ of children who have brushed their teeth every day, but only $1.7 \%$ have done it correctly. Other data related to Clean and Healthy Living Behavior in general, in which there are school-age children who have performed defecation behavior $(\mathrm{BAB})$ correctly in the latrine, which reached $82.6 \%$ while washing hands using the correct soap with the proportion 47\%. In 2007 the behavior of washing hands reached $23.2 \%$, there will be an increase in 2013 to $47 \%$ then defecation behavior in the 
latrine in 2007 reached $71.1 \%$ while in 2013 it became $82.6 \%$. Food consumption behavior that is at risk of threatening the body is in the form of consuming food/drinks, including sweet ones reaching $53.1 \%$, fatty reaching $40.7 \%$ and flavoring reaching $77.3 \%$ (Riskesdas, 2013).

One of the easiest Clean and Healthy Lifestyles to do and has the greatest benefits is Hand Washing with Soap (CTPS). According to Indonesian health data (2015) regarding CTPS, the proportion of people doing CTPS is $47.0 \%$, while in North Sumatra this proportion is only $32.9 \%$ and is included in the five provinces with the lowest proportion. Data on CTPS in Medan City according to the NGO HeartIndo.

\section{Method}

A cross-sectional study was undertaken with 70 people from an elementary school in Medan City. This study aimed to learn about student characteristics, knowledge, habits, facilities and infrastructure, teacher support, and hand-washing behaviour with soap.

In-person interviews with students as respondents are conducted using standardized questionnaires, and observations are made utilizing observation sheets. Frequency distribution, cross-tabulation, and bivariate analysis employing chi-square tests with 95 per cent confidence intervals were used in this study's data analysis.

\section{Results and Discussion}

Table 1. Frequency Distribution of Respondent Variables

\begin{tabular}{llll}
\hline No & variable & Total & Persentase (\%) \\
\hline Age & & & \\
\hline 1. & 6-9 years & 32 & 45.7 \\
2. & 10-13 years & 38 & 54.3 \\
Total & & 70 & 100.0 \\
\hline Gender & & & \\
\hline 1. & Man & 21 & 30.0 \\
2. & Woman & 49 & 70.0 \\
Total & & 70 & 100.0 \\
\hline Knowledge & & \\
\hline 1. & Good & 59 & 84.3 \\
2. & Not Good & 11 & 15.7 \\
Total & & 70 & 100.0 \\
\hline Habit & & & \\
\hline 1. & Good & 27 & 38.6 \\
2. & Not Good & 43 & 61.4 \\
Total & & 70 & 100.0 \\
\hline
\end{tabular}




\begin{tabular}{llll}
\hline \multicolumn{2}{l}{ Facilities and infrastructure } & & \\
\hline $1 . \quad$ Available & 0 & 0 \\
$2 . \quad$ Not Available & 70 & 100.0 \\
Total & 70 & 100.0 \\
\hline \multicolumn{2}{l}{ Teacher Support } & & \\
\hline $1 . \quad$ Good & 70 & 100.0 \\
2. & 0 & 0 \\
Total & Not Good & 70 & 100 \\
\hline Handwashing Behavior with Soap & & \\
\hline 1. & Good & 25 & 35.7 \\
2. & Not Good & 45 & 64.3 \\
Total & & 70 & 100.0 \\
\hline
\end{tabular}

Based on the table above, it shows that the number of respondents aged 6-9 years is 32 students $(45.7 \%)$ and the number of respondents aged $10-13$ years is 38 students $(54.3 \%)$. the most number of respondents were female as many as 49 people (70.0\%) and male sex as many as 21 people (30.0\%). respondents who have good knowledge are 59 people with a percentage $(84.3 \%)$ and respondents who have bad knowledge are 11 people with a percentage (15.7\%). respondents who have good habits are 27 people with a percentage $(38.6 \%)$ and respondents who have bad habits are 43 people with a percentage $(61.4 \%)$. respondents who answered that facilities and infrastructure were available as many as 0 people with a percentage $(0 \%)$ and respondents who answered that facilities and infrastructure were not available were 70 people with a percentage (100\%). Respondents who answered the teacher's support were supported by 70 people with a percentage $(100 \% \%)$. So for the next Teacher Support is no longer analyzed bivariately, because the respondents' answers are homogeneous. respondents with CTPS behavior with a percentage of 25 people $(35.7 \%)$ and respondents with bad CTPS behavior as many as 45 people with a percentage $(64.3 \%)$.

Table 2. Tabulation Between Knowledge and Handwashing Behavior with Soap

\begin{tabular}{|c|c|c|c|c|c|c|c|c|}
\hline \multirow{3}{*}{ No } & \multirow{3}{*}{ Knowledge } & \multicolumn{4}{|c|}{$\begin{array}{l}\text { Handwashing Behavior with } \\
\text { Soap }\end{array}$} & \multirow{2}{*}{\multicolumn{2}{|c|}{ Total }} & \multirow{3}{*}{$\mathbf{P}$} \\
\hline & & \multicolumn{2}{|c|}{ Good } & \multicolumn{2}{|c|}{ Not Good } & & & \\
\hline & & $\mathbf{N}$ & $\%$ & $\mathbf{N}$ & $\%$ & $\mathbf{N}$ & $\%$ & \\
\hline 1. & Good & 24 & 40.7 & 35 & 59.3 & 59 & 100.0 & \multirow{3}{*}{0.083} \\
\hline 2. & Not Good & 1 & 9.1 & 10 & 90.9 & 11 & 100.0 & \\
\hline \multicolumn{2}{|c|}{ Total } & 25 & 35.7 & 45 & 64.3 & 70 & 100.0 & \\
\hline
\end{tabular}

Based on the table above, it shows that of the 70 respondents who have good knowledge with good handwashing behavior with soap, there are 24 with a percentage (34.3\%), who have good 
knowledge with bad handwashing behavior with soap, there are 35 respondents with a percentage ( $50.0 \%$ ). And those who have bad knowledge with good handwashing behavior with soap are 1 respondent with a percentage (1.4\%), who have poor knowledge with bad handwashing behavior with soap there are 10 respondents with a percentage (14.3\%). It means that there is no relationship between knowledge and handwashing behavior at State Elementary School 060916 Medan Sunggal. It is proven that good knowledge is followed by bad hand washing behavior.

Based on the statistical test using the Chi Square test with Knowledge and Handwashing Behavior with Soap at 060916 State Elementary School Medan Sunggal, it was found that the P value $(0.083>0.05)$, so Ho was accepted and Ha was rejected. This means that there is no significant relationship between Knowledge and Handwashing Behavior with Soap.

This study is in line with the research conducted by Saptiningsih, et al. It can be seen that the proportion of respondents with knowledge with hand washing behavior with good knowledge $(\%)$ and not good knowledge $(\%)$. Based on the results of statistical tests obtained p value $=0.475$, so it can be concluded that there is no relationship between knowledge and hand washing behavior in elementary school children 3 Kertajaya Padalarang. The high percentage of children who have good knowledge about hand washing can be due to the fact that from an early age they have been given or taught either by parents or teachers. As stated by Ray, et al (2011) in Pratiwi in his book which says that tofu is defined as remembering a material that has been studied previously. Know is the lowest level of knowledge. Included in this level of knowledge is recalling something specific from all the material studied or stimuli that have been received. So that when the children were asked questions about hand washing, they were able to recall what they had heard before.

According to the researcher, good children's knowledge is not in line with good children's behavior, because as is known that in getting used to and awareness to wash hands is still lacking. Bloom's theory reveals that an important domain for the formation of actions and acceptance of new behavior based on enduring knowledge in a person is knowledge. On the other hand, if knowledge is not realized and based on good behavior, it will not last long and is based on Rogers theory, which states that people who already know (awareness) of a thing will not necessarily behave correctly before the person concerned does several stages until he finally reaches the end. adopt it properly. 
Table 3. Tabulation Between Habits and Handwashing Behavior with Soap

\begin{tabular}{|c|c|c|c|c|c|c|c|c|}
\hline \multirow[t]{3}{*}{ No } & \multirow{3}{*}{ Habit } & \multicolumn{4}{|c|}{$\begin{array}{l}\text { Handwashing Behavior with } \\
\text { Soap }\end{array}$} & \multicolumn{2}{|c|}{ Total } & \multirow{3}{*}{$\mathbf{P}$} \\
\hline & & \multicolumn{2}{|c|}{ Good } & \multicolumn{2}{|c|}{ Not Good } & \multirow[b]{2}{*}{$\mathbf{N}$} & \multirow[b]{2}{*}{$\%$} & \\
\hline & & $\mathbf{N}$ & $\%$ & $\mathbf{N}$ & $\%$ & & & \\
\hline 1. & Good & 19 & 70.4 & 8 & 29.6 & 27 & 100.0 & \\
\hline 2. & Not Good & 6 & 14.0 & 37 & 86.0 & 43 & 100.0 & $<0.001$ \\
\hline Tot & & 25 & 35.7 & 45 & 64.3 & 70 & 100.0 & \\
\hline
\end{tabular}

Based on the table above, it shows that of the 70 respondents who have good habits with good handwashing behavior with soap, there are 19 with a percentage $(27.1 \%)$, who have good habits with bad handwashing behavior with soap, there are 8 respondents with a percentage (11.4\%). And those who have bad habits with good handwashing behavior with soap are 6 respondents with a percentage $(8.6 \%)$, who have bad habits with bad handwashing behavior with soap there are 37 respondents with a percentage (52.9\%). It means that there is a relationship between habit and hand washing behavior at State Elementary School 060916 Medan Sunggal. It is proven that bad habits are followed by bad hand washing behavior.

Based on statistical tests using the Chi Square test with Habits with Handwashing with Soap Behavior at State Elementary School 060916 Medan Sunggal, the results obtained were P value $(0.000<0.05)$, so Ho was rejected and Ha was accepted. This means that there is a significant relationship between Habits and Handwashing Behavior with Soap. This study is in line with research conducted by Kamaluddin (2016), it can be seen that the proportion of respondents with the incidence of diarrhea was found in mothers who had poor hand washing habits, namely $75 \%$. Handwashing with Soap with Diarrhea in Toddlers in the Work Area of the 4 Ulu Health Center, Seberang Ulu I District, Palembang.

Based on the results of the study, that of the 27 respondents who answered good habits as many as 19 respondents with bad hand washing behavior with soap were 8 respondents. According to the researcher's assumption, the habit of washing hands is in fact still a challenge, especially for children because of the culture of school children who are not accustomed to washing their hands with soap. This means that students have a culture of washing their hands only with water. Thus, this culture shows that students' behavior in washing hands with soap is not good because good behavior should be washing hands with soap, not just washing hands with water.

\section{Conclusions and Suggestions}

1. Based on the research, the majority of students' knowledge of 060916 Medan Sunggal Elementary School is good $(40.7 \%)$ but Handwashing Behavior with Soap is not good 
(59.3\%). That is, good knowledge does not mean accompanied by good behavior as well. So that the results obtained, there was no significant relationship between Knowledge and Handwashing Behavior with Soap on State Elementary School Students 060916 Medan Sunggal $(\mathrm{p}=0.083>0.05)$. The majority of students in Medan Sunggal Elementary School 060916 are not good and the behavior of washing hands with soap is not good (52.9\%). That is, bad habits are accompanied by bad behavior. So that the results obtained, there is a significant relationship between Habits and Handwashing Behavior with Soap in State Elementary School Students 060916 Medan Sunggal $(p=0.000<0.05)$.

2. To the Medan Sunggal Health Office in fostering UKS at SDN 060916 Medan Sunggal in particular and other schools to focus on fostering Handwashing with Soap Behavior through improving facilities and infrastructure for washing hands with soap as a facility for students to practice handwashing and washing hands properly.

\section{References}

Andreasen, A.R. 1995. Marketing Social Change: Changing Behavior to Promote Health, Social Development, and the Environment. Georgetown University Press.

Bustan, M. 2015. Manajemen Pengendalian Penyakit Tidak Menular. Jakarta : Rineka Cipta

Departemen Kesehatan RI, 2013. Laporan Riset Kesehatan Dasar Tahun 2013. Badan Penelitian dan Pengembangan Kesehatan Departemen Kesehatan RI. Jakarta

Janis, dkk.2014. Gambaran Perilaku Hidup Bersih dan Sehat (PHBS) pada Siswa Sekolah Dasar Negeri 30 Manado. Manado : Jurnal Fakultas Kesehatan Masyarakat Universitas Sam Ratulangi

Kamaluddin, dkk, 2016. Hubungan Kebiasaan Mencuci Tangan, Kebiasaan Mandi dan Sumber Air dengan Kejadian Diare pada Balita di Wilayah Kerja Puskesmas 4 Ulu Kecamatam Seberang Ulu I Palembang. Jurnal Kedokteran dan Kesehatan: Universitas Sriwijaya

Kartika, dkk. 2016. Faktor-faktor yang berhubungan dengan perilaku cuci tangan pakai sabun pada siswa Sekolah Dasar Negeri Sambitoto 01 kota Semarang. Semarang : Jurnal Kesehatan Mayarakat volume.4 Nomor 5, oktober 2016 (ISSN:2356-3346).

Knutson, Andy L. 1985. The Individual, Society and Health Behavior. New York : Russel Sage Fondation

Maryunani, Anik. 2017. Perilaku Hidup Beersih dan Sehat (PHBS). Jakarta : CV Trans Info Media

Mubarak, dkk, 2007. Promosi Kesehatan: Sebuah Pengantar Proses Belajar Mengajar dalam Pendidikan

Mukminah, dkk, 2016. faktor-faktor yang berhubungan dengan praktik cuci tangan pakai sabun pada siswa SD diwilayah kerja Puskemas Banyuurip Purworejo. Purworejo : Jurnal Kesehatan Mayarakat Volume 4 No. 5 Oktober 2016 (ISSN :2356-3346)

Nugraheni, dkk. 2010. Praktek Cuci Tangan Pakai Sabun di Sekolah pada Siswa Sekolah Dasar di Kota Semarang. Semarang : Jurnal Promosi Kesehatan Indonesia Vol. 5 No. 2 Agustus 2010

Notoatmodjo S. (2003) Metode Penelitian Kesehatan. Jakarta : RINEKA Cipta 
Notoatmodjo, 2003. Pendidikan dan Perilaku Kesehatan. Jakarta : Rineka Cipta

Notoatmodjo, 2012.Promosi Kesehatan dan Perilaku Kesehatan. Jakarta :Rineka Cipta

Nugraheni, dkk, 2010. Praktek Cuci Tangan Pakai Sabun di Sekolah pada Siswa Sekolah Dasar di Kota Semarang. Semarang : Universitas Diponegoro

Pratiwi, 2017. Pengetahuan dan Perilaku Cuci Tangan Pada Anak Sekolah Dasar di Kota Malang. Rapat Kerja Fakultas Ilmu Kesehatan : Peningkatan Keilmuan Solusi Tantangan Profesi Kesehatan

Risnawaty, 2016. Faktor Determinan Perilaku Cuci Tangan Pakai Sabun (CTPS) Pada Masyarakat Di Tanah Kalikedinding. Semarang : Universitas Airlangga

Riyanto, Agus. 2018. Aplikasi Metode Penelitian Kesehatan. Yogyakarta : Nuha Medika

Ryadi, 2016. Ilmu Kesehatan Masyarakat. Yogyakarta : ANDI

Saptiningsih, dkk. 2012. Faktor-faktor yang Berhubungan dengan Perilaku Mencuci Tangan pada Anak Sekolah Dasar Negeri 03 Kertajaya Padalarang. Kertajaya: Jurnal Ilmu Keperawatan

Sari, dkk. 2016. Faktor-faktor yang Berhubungan dengan Perilaku Hidup Bersih dan Sehat sebagai Upaya untuk Pencegahan Penyakit Diare pada Siswa SD N Karangtowo Kecamatan Karang Tengah Kabupaten Demak. Demak : Jurnal Kesehatan Masyarakat Volume 4, Nomor 3, Juli 2016 (ISSN: 2356-3346).

Soetjiningsih. 2009. Tumbuh Kembang Anak. Jakarta: EGC.

Ulfah, 2018. Analisis Determinan Perilaku Personal Hygiene Siswa Sd Negeri 141 Palembang Tahun 2017. Jurnal Husada Mahakam: STIK Bina Husada Palembang

Wokas, Arman. 2018. Gambaran tentang Perilaku Hdup Bersih dan Sehat di Sekolah Dasar Negeri Gumpang 01 Kartasura Sukoharjo. Universitas Muhammadiyah Surakarta : Jurnal Fakultas Ilmu Kesehatan Keperawatan.

WHO. 2002. Kader Kesehatan Masyarakat (The Community Health Worker). Jakarta : EGC 